\title{
Increasing the efficiency of Russian uranium mining enterprises in conditions of excessive supply
}

\author{
A.Dudina $^{1}$, M. Shabalov ${ }^{2}$, L. Nikolaichuk ${ }^{1}$ \\ ${ }^{1}$ Department of Economics, Accounting and Finance, Saint Petersburg Mining University, St. \\ Petersburg, Russia \\ ${ }^{2}$ Center for Digital Technologies, Saint Petersburg Mining University, St. Petersburg, Russia
}

\begin{abstract}
The article describes the current situation in the global uranium concentrate market, explains the reasons for the formation of an excess amount of finished goods and the subsequent decreasein prices. The authorsevaluated the prospects of using market mechanisms to improve the financial results of Russian uranium mining enterprises. The location of the main mining centers in comparison with the centers of consumption of finished goods, pricing for the products of uranium mining companies, the dynamics of price changes over the past 20 years, the influence of nonmarket factors on the supply of finished products are analyzed.This study led to the conclusion that the expectation of changes in the market situation is not viable in a long term. The authors outlined the direction to improve the profitability of mining enterprises by introducing technological changes aimed at reducing the cost of the final product.
\end{abstract}

\section{Introduction}

Nuclear power plants account for $11 \%$ of all electricity generated in the world [1]. A key element necessary for the production of nuclear fuel that feeds the nuclear power reactor is uranium. On the one hand, uranium mining is not much different from mining any other metal (exploration, obtaining a license, developing a mine, closing a mine, and rehabilitating the land plot), but at the same time, there are several features in the industry that create problems and significantly increase production costs, such as radiation safety, radioactive waste management, distrust, and public wariness. At the same time, the International Energy Agency (IEA) predicts that by 2050 global energy demand will increase by more than $80 \%$, and the question of what share will be in nuclear energy remains open. With proper operation and compliance with radiation safety rules, nuclear energy is a reliable and efficient source of carbon-free energy, which is important because as of today, Russia does not pay due attention to reducing carbon dioxide emissions; moreover, $\mathrm{CO}_{2}$ emissions have increased recently [2]. As a result, Russia continues to be in a leading position among the countries with the largest emissions in the world [3]. An increase in the volume of electricity generated at nuclear power plants will reduce $\mathrm{CO}_{2}$ emissions and inevitably lead to an increase in the demand for natural uranium, which indicates the relevance of the chosen topic. 
The uranium market is characterized by strong volatility; over the past 15 years, the price has changed from $\$ 300$ to $\$ 41$ per kilogram of uranium concentrate [4]. A significant negative impact on the formation of low prices over the past decade has been the accumulation of excessive uranium reserves in the warehouses of mining enterprises. In conditions of excess supply, the excess price over the cost of developing, 5 large uranium mines with a capacity of 12 thousand tons of uranium per year, were transferred to conservation mode [5]. Unfavorable market conditions make it difficult to introduce innovations in the industry and reduce the volume of exploration work.

The Russian uranium industry is represented by the company AO Atomredmetzoloto, which is part of the enterprises of the State Atomic Energy Corporation Rosatom, which is developing deposits in the Trans-Baikal Territory, the Republic of Buryatia, and the Kurgan Region. The mineral and raw material base of Russian uranium was 520.7 thousand tons at the end of 2018, approximately $8 \%$ of the total global reserves, 4 th place in the world after Australia, Kazakhstan, and Canada [6]. At the same time, , ARMZ' operations J are unprofitable, like those of the majority of similar uranium mining enterprises. The study analyzes the dynamics and current state of the world uranium market, identifies and evaluates factors that influence the formation of a negative financial result of AO ARMZ. The purpose of the paper is to fulfill the need to introduce an integrated system of measures aimed at reducing the cost of the production process instead of expecting an improvement in market conditions in the long term.

\section{Review of literature}

This scientific article examines the growing role of the nuclear industry in generating environmentally-friendly electricity [7], discusses the impact of the Fukushima accident in 2011 on the subsequent decrease of world uranium prices [8], and assesses the prospects for expanding the uranium mineral resource base [9]. Much attention in the scientific community is paid to the use of ISL technology in uranium mining, as the most effective from an economic and environmental point of view [10,11]. The use of this technology by Russian mining enterprises is limited by the peculiarities of the geological structure of the largest deposits. Some researchers focus their studies on the discovery of fundamentally new methods, in particular, from seawater [12]. In the literature, the problem of high costs for ensuring radiation and nuclear safety is considered as the main element in the rise in the cost of finished goods [13]. The negative impact of low market prices for raw materials on the development of the uranium mineral resource base remains important, which leads to a decrease in explored deposits with low production costs [14]. The main focus in scientific works is the expectation of an increase in the price of uranium with an increase in nuclear power and the construction of new nuclear power plants $[15,16]$.

Statistics are collected and published by the International Atomic Energy Agency (IAEA), including the Power Reactor Information System (PRIS), World Distribution of Uranium Deposits (UDEPO), and the Integrated Nuclear Fuel Cycle Information System (INFCIS). Analytical data and forecasts are provided by the consulting company UxC and the World Nuclear Association (WNA).

\section{Methodology}

In the course of the study, an analysis of statistical data was carried out aimed at identifying trends in the development of the world uranium market since the beginning of the 21 st century, and scientific articles and annual reports of uranium mining enterprises were analyzed. A factor analysis of the financial results of the Russian uranium mining 
enterprise AO Atomredmetzoloto was performed to assess the influence of various factors on the formation of losses from core activities.

Official statistics, IAEA information systems, reports of nuclear industry enterprises were used in the study.

\section{Analysis}

\subsection{Global market analysis}

Uranium production is the initial stage of the nuclear fuel cycle (NFC), which includes uranium mining, uranium enrichment, nuclear fuel production, nuclear power generation, spent nuclear fuel storage in basins and its processing, radioactive waste, and spent nuclear fuel disposal. The final product of production - uranium oxide concentrate $\left(\mathrm{U}_{3} \mathrm{O}_{8}\right)$, is a dry yellow saturated uranium concentrate, hence its name "yellowcake". Purified from impurities and enriched in isotope 235, uranium concentrate is used to produce nuclear fuel, which is necessary for the operation of nuclear power plants, nuclear submarines, and icebreakers. Uranium production volumes are determined based on reactor requirements for nuclear fuel; in other words, enterprises are engaged in the production of nuclear fuel from the demand for uranium. Uranium supply is divided into primary, direct mining and processing of uranium ore, and secondary, for example, processing of depleted uranium hexafluoride, spent nuclear fuel, dilution of weapons-grade uranium with depleted uranium, and stocks of energy companies. Uranium obtained from secondary sources satisfies about $10 \%$ of the world's uranium needs [17].

The uranium market is characterized by closeness, strong volatility, a limited number of consumers and producers: $80 \%$ of all produced uranium goes to state corporations. $90 \%$ of primary uranium is mined in countries where further production of nuclear fuel and electricity is minimal or completely absent (two-thirds of all global uranium production is in Kazakhstan, Canada, and Australia), while $90 \%$ of uranium concentrate consumption occurs in countries that have no primary sourcesof their own [18]. Uranium supplies are highly dependent on government trade policies. The leader of the uranium concentrate market is the Kazakhstan company NAC Kazatomprom, which accounts for $22 \%$ of the total global production of uranium oxide [4]. The top three mining companies include the uranium mining assets of Rosatom State Corporation: AO ARMZ and Uranium One Holding, jointly accounting for $14 \%$ of world production [6]. The leaders of world uranium production are shown in Figure 1.2.

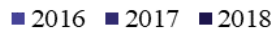

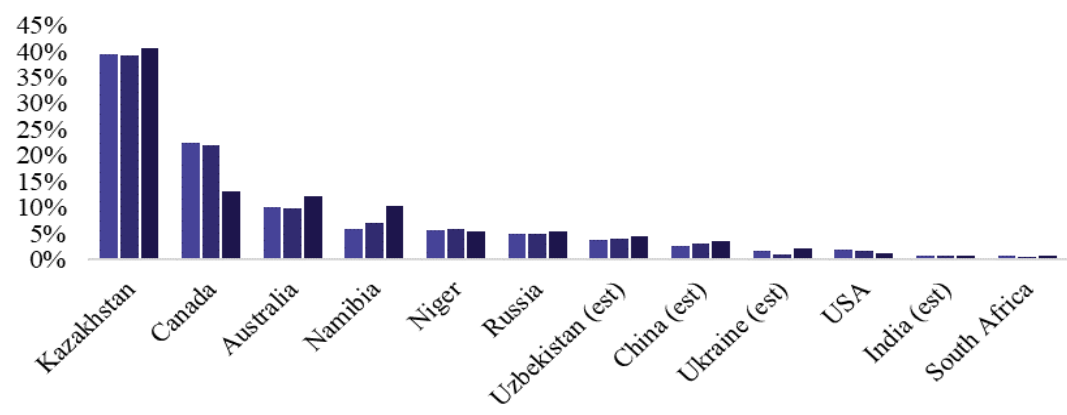

Fig. 1. Uranium production by world countries 2016-2018, \%. 


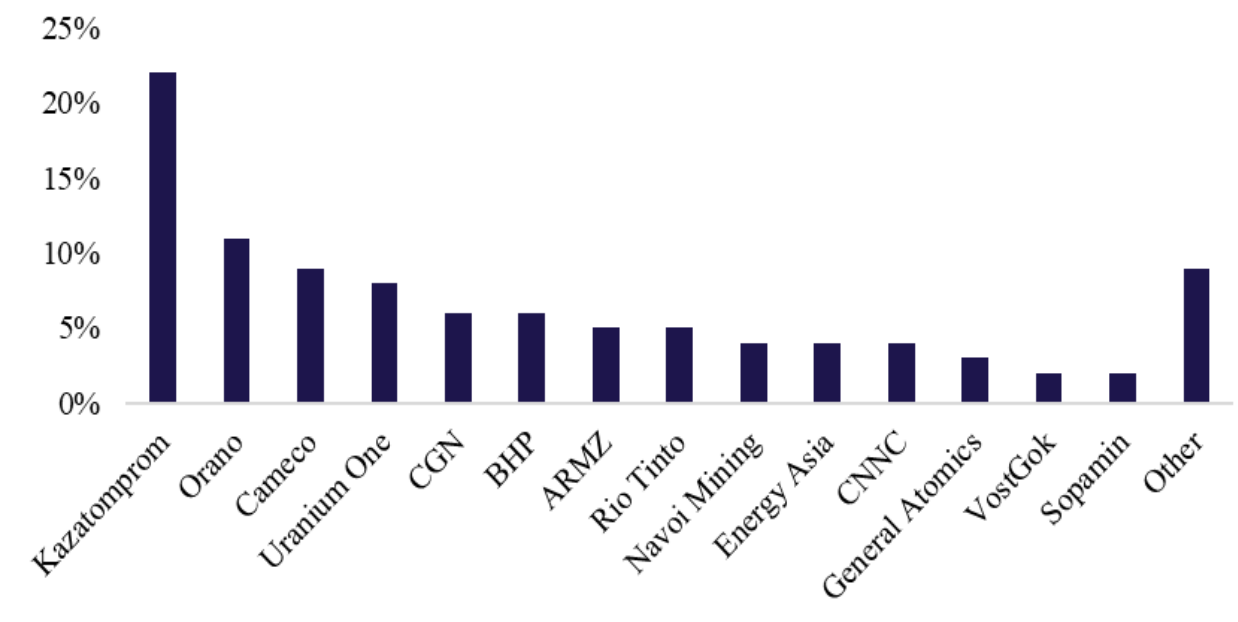

Fig. 2. Uranium production by the largest companies $2018, \%$.

Uranium supplies are carried out under long-term contracts concluded between mining enterprises and producers of uranium fuel and nuclear electricity. In 2019, 53\% of world production was supplied under long-term contracts, the remaining $47 \%$ came from the short-term (spot) market, which is represented by traders most often owned by uranium producers [4]. Until 2010, the short-term market accounted for no more than $20 \%$ of the supply of uranium, but with the increasing interest of companies in reducing the terms of contracting, spot contracts began to gain greater popularity. The price of a long-term contract is traditionally higher than of the spot ones but, in general, they have similar dynamics. In 2007, after the flooding of the largest uranium deposits in Canada at that time (Cigar Lake, the Athabasca River), a "uranium bubble" formed on the background of uncertainty about the supply of uranium to the market. The price increased by $47 \%$ (from $\$$ 89 per pound to $\$ 136$ per pound), but by the beginning of 2008 , it had fallen to $\$ 88$ per pound. During the period of maximum demand, the New York Mercantile Exchange and the Chicago Mercantile Exchange began to conclude uranium futures, where participants can be not only energy holdings but also financial investors, but such futures are not popular with investors. After the Fukushima accident in 2011, the countries of Germany, France, Great Britain, the USA, and Japan, i.e., the largest players in the nuclear industry, began to reduce the volume of nuclear production.In Germany, the concept of energy development and the role of nuclear generation in the structure of the country's energy balance was completely revised at the legislative level [19]. Since 2011, 137 power units have been decommissioned in these countries. Uranium demand has fallen, the average annual price, which in 2011 was $\$ 57$ per pound, began to decline, reaching a minimum on November 2016 (\$19 per pound) [5].

In the same 2016, global uranium production reached its maximum level since 1988, amounting to 62 thousand tons, a significant part of which remained unclaimed, because of the closure of nuclear power plants, and settled in the warehouses of mining enterprises. 


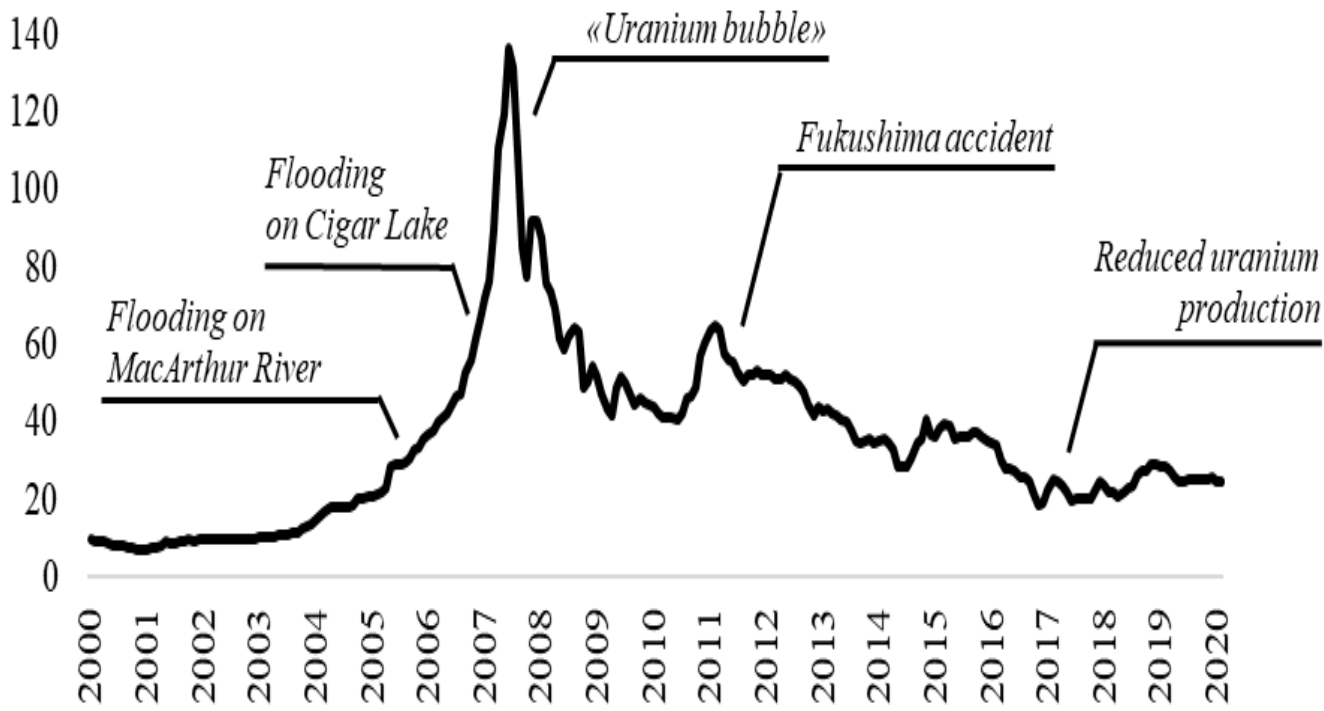

Fig. 3. Dynamics of average annual spot prices for uranium, $\$ / 1 b$ (compiled by the author based on NYMEX data, 2020).

Amid a supply glut in the market, global production of uranium concentrate began to decline. In 2018, world production amounted to 53 thousand tons, down 9\% from 2017. The price was expected to recover in the short term as a result of production cuts, , as well as speculative actions by financial investors in the futures market, the price will recover in the short term, but remained low, around \$ 24 per pound, until the end of March 2020. The dynamics of spot prices is presented in Figure 3. On March 23, 2020, the Canadian Cameco Corporation announced a production shutdown at the Cigar Lake deposit, the largest in the world (13\% of primary uranium was mined here in 2018), in connection with preventing the spread of COVID-19. Following Cameco, on April 7, Kazatomprom also transferred its mines for conservation; uranium mining was completely suspended in South Africa and Namibia. Resumption of production is expected no earlier than in the beginning of August.Given that nuclear power plants continue to operate during the pandemic, and the largest uranium mining companies temporarily stopped production, the price of uranium began to rise: as of 01.05 .2020 , the spot market price was $\$ 34.05$ per pound, a $39.8 \%$ increase since the end of March. Against the background of an increase in the delivery time and uncertainty with international supplies of uranium, a further increase in prices is expected, up to the level of 2011.

The most effective and competitive is the extraction of uranium using in situ leaching (ISL); it differs from traditional mining methods (underground or open-cast mining) by lower capital and operating costs and lower environmental impact. The share of uranium mined using ISL technology increased from $20 \%$ in 2005 to $55 \%$ in $2018.39 \%$ falls on open-pit and underground development of uranium deposits, another $6 \%$ of uranium is mined as a by-product [20]. UxC predicts that asa result of stock depletion,production capacities using ISL will be reduced starting in 2028.

According to the Information System for Power Reactors (PRIS, IAEA), 442 nuclear power units are currently operating in the world and 53 are under construction. The change in nuclear capacity is shown in Figure 4. The growth of the nuclear industry is observed in 
Southeast Asia and the Middle East, mainly in China, Korea, and India.According to existing forecasts, the Indian economy will grow at a double-digit pace in the near future, which makes this country an attractive target for power generation companies [21].

\section{-Reactors in operation $\quad$ Reactors under construction}

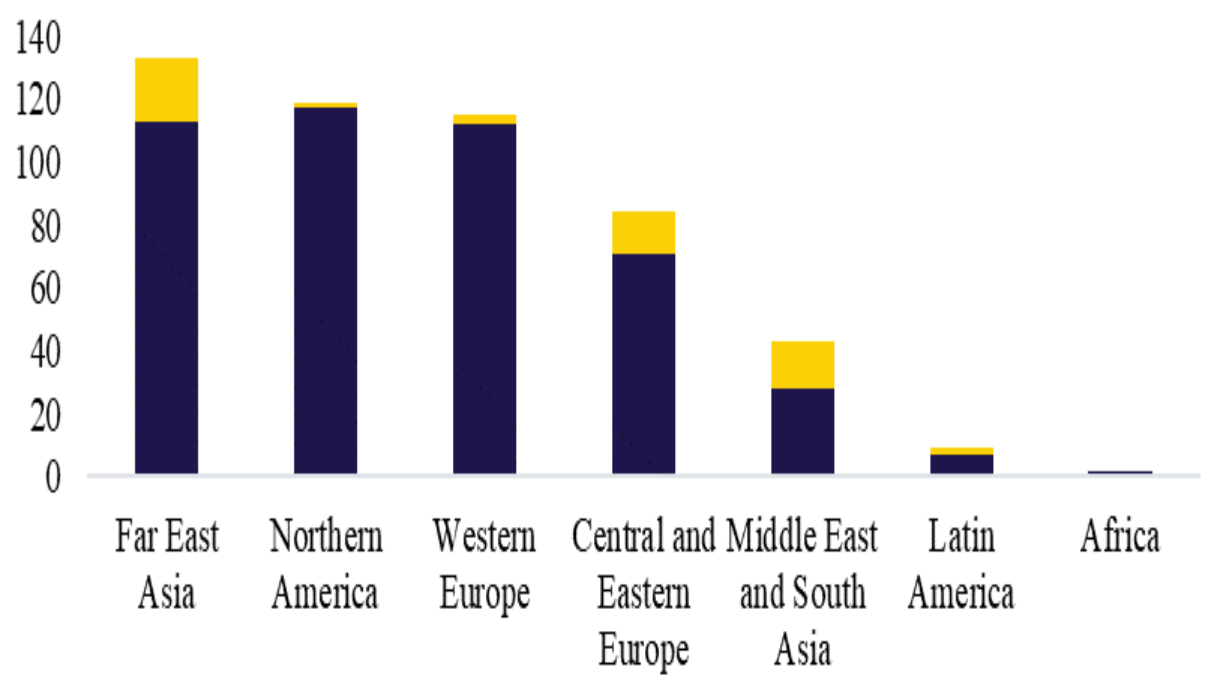

Fig. 4. Regional distribution of nuclear capacity by capacity, MW (compiled by the author based on PRIS, IAEA data, 2020).

Given the reduction in uranium supply from secondary sources and the increase in global needs for reactors, the World Nuclear Association (WNA) forecasts an increase in uranium demand by $77 \%$ by 2035 to 94 thousand tons (baseline forecast).

\subsection{Analysis of the Russian uranium mining industry}

The only company producing uranium in Russia is AO ARMZ (Atomredmetzoloto), which is part of the enterprises of Rosatom State Atomic Energy Corporation. AOARMZ manages Russian uranium mining assets: AO PPGHO in the Trans-Baikal Territory, AO Khiagda in the Republic of Buryatia, AO Dalur in the Kurgan region.Consumers of ARMZ's products are also Rosatom State Corporation enterprises, such asAO Tekhsnabexport, AO TVEL, which need uranium concentrate for nuclear fuel production. Over the past 10 years, ARMZ has received no profit in its core business; in particular, the company's loss amounted to 7.9 billion rubles in 2017 and 4.1 billion rubles in 2018. The AO Dalur and the AO Khiagda, which are part of the ARMZ, received a profit of 316 and 105 million rubles respectivly in 2018; the loss of the entire holding was formed based on the results of the activities of the largest mining asset of ARMZ, AO PPGHO (about 50\% of all uranium produced by the holding is mined here), for which 2018 ended with a loss of 4.4 billion rubles. In the company's statements, the main cause of the loss is the drop in the price of uranium as a result of the excess of uranium supply on the market. To assess the causes of the loss, a factor analysis of the financial statements of AO PPGHO 2017-2018 was carried out; the initial data and results of the factor analysis are presented in Tables 1 and 2. 
Table 1. Initial data for factor analysis.

\begin{tabular}{|c|c|c|c|}
\hline & 2017 & $\begin{array}{c}2018 \text { in prices of } \\
2017\end{array}$ & 2018 \\
\hline Revenues, thousand rubles & $\begin{array}{l}11546 \\
100\end{array}$ & 12615569 & 9446893 \\
\hline Cost of sales, thousand rubles & $\begin{array}{c}(10 \\
430623)\end{array}$ & $\left(\begin{array}{llll}1 & 3 & 383 & 823\end{array}\right)$ & $\begin{array}{c}(10 \\
717567)\end{array}$ \\
\hline Gross profit (loss), thousand rubles & 1115477 & 1009878 & 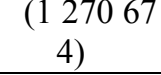 \\
\hline
\end{tabular}

Table 2. Results of factor analysis of AO ARMZ for 2017-2018.

\begin{tabular}{cc}
\hline Factors causing the change in profit & Change, + --, thousand rubles \\
\hline Total change in profit in the reporting year & -2386151 \\
Price change & -1141824 \\
Change in cost & -1138728 \\
Change in volume of sales & -92494 \\
\hline
\end{tabular}

According to the results of factor analysis, we can be conclude that a decrease in the price of products and an increase in the cost of production approximately equally influenced the decrease in revenue in the reporting year and the formation of loss. The decrease in sales lesof an impact on the loss, but also led to a decrease in financial results. The decrease in prices and an increase in the cost of production of the main product of AO PPGHO - uranium oxide - had the greatest impact on the decline in the financial result in the structure of production.

The decrease in natural uranium prices in 2018 was caused by the excess of uranium supply in the world market. Due to the peculiarities of pricing and market instability, it is not possible to increase the revenue of AO PPGHO by increasing the price of uranium oxide: the products are supplied under long-term contracts. Given the impossibility of influencing the price, the company needs to reduce costs to obtain positive financial results for the year. The high cost of production is formed because of the complexity of mining uranium deposits, high capital and operating costs. Dalur and Khiagda are developing their uranium deposits using ISL, while PPGHO is developing underground mining. The use of ISL at PPGHO is impossible due to the specifics of the geological parameters of the constituent rocks.

\section{Armz's ways out of loss}

Considering the expected growth in demand for uranium products due to the growth in the need for reactors for nuclear fuel, as well as the availability of economically successful foreign assets, the question arises of the need to create an economic mechanism to regulate the activities of ARMZ. The consequences caused by the spread of COVID-19 have once again shown the vulnerability of international supplies, their dependence on political, epidemiological, and other factors, which only proves the need to support mining enterprises in the Russian Federation. The Russian nuclear industry is unique in that it concentrates all the links of the nuclear fuel cycle on its territory, which protects against foreign economic risks. In addition, ARMZ is engaged in the production of strategic raw materials that are necessary to ensure the operation of the defense industry, and the closure of even unprofitable mining enterprises will inevitably lead to the loss of the possibility for the development of existing production technologies. Therefore, it is necessary to look for 
ways to bring AO ARMZ company out of loss.

For further development of the Russian mining industry, it is necessary to reduce the cost of production, switch to the principles of "lean production", and increase technological and organizational efficiency [22]. The proposed way to take ARMZ out of loss is to optimize the production process by digitalizing the life cycle of reserves and the operation of the mining complex. The introduction of uninhabited technologies will reduce the costs of radiation protection, ventilation, and ventilation tunneling, which will ultimately lead ARMZ out of unprofitableness without taking into account the expectation of an increase in themarket price in the long term.It seems expedient to use the software resources of Rosatom State Corporation, which, in the context of the active development of digital technologies, will ensure in the future not only the survival of the enterprise but also reaching a qualitatively new level [23]. The introduction of digital methods is already being implemented at the AO Khiagda fields within the framework of the Smart Mines project, and the PPGHO hydrometallurgical plant is undergoing technical re-equipment of the heap leaching area, which will be fully digitalized, and the commissioning of this facility is scheduled for 2021.

In parallel with the implementation of projects to digitalize production, it is necessary to carry out geological exploration to search for "cheap" deposits in which the cost of production is less than $\$ 80$ per kilogram. The IAEA reports a $48 \%$ reduction in "cheap" deposits since 2016, while Ux Consulting reports that production costs are lower than the market price by only $40 \%$ at operating mines (data as of early 2020 ).

On the other hand, the highest added value of products manufactured by Rosatom State Corporation is formed at such stages of the nuclear fuel cycle as the production of nuclear fuel and electricity. Uranium production accounts for only $5-10 \%$ of the price of electricity generated by nuclear power plants. As a result, even if there is a loss-making mining division, the profitability of sales (in net profit) of the entire state corporation amounted to $20.05 \%$ (2018), which indicates the efficiency of NFC implementation by the Rosatom state corporation.

\section{Conclusion}

The nuclear industry is a promising area for the generation of clean energy, though it faces political constraints and a lack of public support. Despite the projected increase in global reactors' needs, the uranium market situation is unfavorable: the production of uranium concentrate has been declining since 2016, while the price has remained low. While it is difficult to estimate how long or short the price increase will be as a result of limiting production capacities in the context of preventing the spread of COVID-19, however, the introduced epidemiological measures have led to a peak in the decade-long drop in supply over demand; mining companies begun to get rid of accumulated reserves which hampered the growth of prices but at the same time interruptions in international supplies of uranium posed a threat to disrupt the entire production chain. There is a tendency to reduce the "cheap" deposits, the lower secondary sources of uranium.

A factor analysis of the financial statements of the Russian uranium mining enterprise ARMZ indicates the formation of negative financial results, taking into account the decline in the uranium supply price and the high cost of production. The geological features of the deposits developed by the enterprise, as well as the specifics of the natural uranium market, do not allow the company to lose out in the short term. Nevertheless, it is considered advisable to modernize the technological process of uranium ore mining, introduce new technologies for digitalization and informatization of the production process. Thus, the analysis of the world market presented in the article shows that it is not advisable to expect a sharp improvement in the market situation; the proposed way to overcome losses is to 
modernize the technological process of uranium ore mining and introduce new technologies for digitalization and informatization of the production process.

\section{References}

1. IAEA Steps up Support for Nuclear Facility Operators during COVID-19 CrisisURL: https://www.iaea.org/newscenter/news/iaea-steps-up-support-for-nuclear-facilityoperators-during-covid-19-crisis (accessed 21.03.2020).

2. P. Tcvetkov, A. Cherepovitsyn, Prospects of CCS projects implementation in Russia: Environmental protection and economic opportunities. Journal of Ecological Engineering, 172, 24-32 (2016).

3. N. Romasheva, A. Ilinova, CCS projects: How regulatory framework influences their deployment. Resources, 84 (2019).

4. Cameco Corp. 2019. Annual Report 2019 URL: https://www.cameco.com/invest/financial-information/annual-re ports/2019(accessed 05.05.2020).

5. NYMEX UX1! URL: https://ru.tradingview.com/symbols/NYMEX-UX1!/ (accessed 06.05.2020).

6. AO ARMZ. 2018. Annual Report 2018URL: http://www.armz.ru/aktsioneram-iinvestoram/raskrytie-informatsii/godovaya-bukhgalterskaya-i-finansovayaotchetnost(accessed 21.03.2020)

7. N. A. Sepulveda, J. D. Jenkins, F. J. de Sisternes, R. K. Lester, The role of firm lowcarbon electricity resources in deep decarbonization of power generation, Joule, 211, 2403-2420 (2018).

8. M. Gaspar, N. Mayhew, URAM-2018: Ebb and Flow - the Economics of Uranium MiningURL: https://www.iaea.org/newscenter/news/uram-2018-ebb-and-flow-theeconomics-of-uranium-mining (accessed 20.04.2020).

9. F. Caruso, IAEA Unveils Unique World Uranium Map URL: https://www.iaea.org/newscenter/news/iaea-unveils-unique-world-uranium-map (accessed 02.05.2020).

10. S. H. Farjana, N. Huda, M. A. P. Mahmud, C. Lang, Comparative life-cycle assessment of uranium extraction processes. Journal of Cleaner Production, 202, 666-683 (2018).

11. M. Seredkin, A. Zabolotsky, G. Jeffress, In situ recovery, an alternative to conventional methods of mining: Exploration, resource estimation, environmental issues, project evaluation, and economics. Ore Geology Reviews, 79, 500-514 (2016).

12. C. W. Abney, R. T. Mayes, T. Saito, S. Dai, Materials for the recovery of uranium from seawater, Chemical Reviews, 11723, 13935-14013 (2017).

13. B. A. Jones, The social costs of uranium mining in the US Colorado plateau cohort, 1960-2005, International Journal of Public Health, 624, 471-478 (2017).

14. A. I. Ahmed, R. G. Bryant, D. P. Edwards, Where are mines located in Sub Saharan Africa and how have they expanded overtime? Land Degradation and Development, (2020).

15. W. Xing, A. Wang, Q. Yan, S. Chen, A study of China's uranium resources security issues: Based on analysis of china's nuclear power development trend, Annals of Nuclear Energy, 110, 1156-1164 (2017).

16. M. Ho, E. Obbard, P. A. Burr, G.Yeoh, A review of the development of nuclear power reactors, Paper presented at the Energy Procedia, 160 459-466 (2019). 
17. IAEA Bulletin Uranium: From Exploration to RemediationURL: https://www.iaea.org/publications/magazines/bulletin/59-2 (accessed 21.03.2020)

18. Uranium Mining OverviewURL: https://www.world-nuclear.org/informationlibrary/nuclear-fuel-cycle/mining-of-uranium/uranium-mining-overview.aspx (accessed 15.04.2020)

19. M. Paschke, Legal challenges of the new energy policy in Germany. Journal of Mining Institute, 226, 487-496 (2017).

20. World Uranium Mining Production URL: https://www.world-nuclear.org/informationlibrary/nuclear-fuel-cycle/mining-of-uranium/world-uranium-mining-production.aspx (accessed 21.04.2020)

21. P. A. Lyalina, V. D. Dyakonova, L. A. Podolyanets, A. L. Feldman, Interaction between Russia and India in the field of hydrocarbon logistics, Journal of Social Sciences Research, 2018 Special Issue 3, 440-447 (2018).

22. V. S. Litvinenko, The digital economy as a factor in the technological development of the mineral sector, Natural Resources Research, 293, 1521-1541 (2020).

23. Y. Zhukovskiy, D. Malov, Concept of smart cyberspace for smart grid implementation, Paper presented at the Journal of Physics: Conference Series, 10154 (2018). 